\title{
Practical Issues of Partial Onsite Sanitation Systems: Two Case Studies from Sri Lanka
}

\author{
I.P.P. Gunawardana, L.W. Galagedara ${ }^{1}$ and S. De Silva ${ }^{2 *}$ \\ Postgraduate Institute of Agriculture \\ University of Peradeniya \\ Sri Lanka
}

\begin{abstract}
Sanitation systems have vast differences among the countries as well as among different regions within the country. In Sri Lanka, over $90 \%$ of buildings rely upon onsite sanitation systems and most popularly with water sealed latrines connected to septic tanks or cesspits, however, the sanitizing the septage or nightsoil is required further treatment before disposing of or reuse. The filled cesspits/septic tanks are simply emptied using the suction trucks by the local authorities. Since the septage is removed from the site, the whole system can be named as partial onsite sanitation system (POSS). The practical problems that POSS may lead to are discussed throughout the paper using two case studies in Sri Lanka. Methodology follows both quantitative and qualitative social research techniques such as structured interviews with operators, downstream community, and health and sanitary workers, and collecting data on influent and effluent characteristics. Quantitative data were analyzed and interpreted using descriptive statistics. This paper provides a description of the complex issues that may stem out of POSS and possible factors for the sustainability of such systems. It is found that community participation, knowledge on sanitation, and institutional commitment were required to sustain the system which were lacking in two cases studied. It is advisable to develop programs and strategies to build up the capacity of local authorities to manage the sanitation systems and even to raise the awareness of community for good care of the onsite components.
\end{abstract}

Key words: Nightsoil, Partially onsite sanitation system, Sanitation, Septage, Septic tanks.

\section{INTRODUCTION}

A sanitation system is a comprehensive combination of product-specific technology components designed to process each product from the point of generation until the point of reuse or disposal. Sanitation system contrast to the sanitation technology by including all the aspects of management of human waste, and the system contains a mixture of different technologies. According to the assessment of sanitation systems and technologies by Network for Sustainable Approaches for large scale implementation of Sanitation in Africa (NETSSAF), a sanitation system comprises of few processes, namely; user interface, onsite treatment or collection and storage, transportation, offsite treatment, reuse or disposal (Zurbrügg and Elizabeth, 2008). All of the above phases are important to consider for an evaluation of a sanitation system as the technologies differ in each phase and all the processes play a specific role to achieve good sanitary condition.

To whom correspondence should be addressed: saliyades@pdn.ac.lk

Department of Agricultural Engineering, Faculty of Agriculture, University of Peradeniya, Sri Lanka

Department of Agricultural Extension, Faculty of Agriculture, University of Peradeniya, Sri Lanka 
The main two types of sanitation systems are the onsite (decentralized) and offsite (centralized) systems. In Sri Lanka, very few (about ten) centralized sanitation systems are available only for community schemes such as Mattegoda, Digana and Rathdolugama. Centralized sanitation system consists of a collection system (sewers) to transport sewage to a centralized treatment plant in an off-site location of the settlement. The disposal/reuse of the treated effluent, usually far from the point of origin, thus it is also referred to as offsite management. Decentralized sanitation technologies include all the component onsite, but may be individual or communal systems, and similarly referred as onsite sanitation. Majority $(76.5 \%)$ of the households in Sri Lanka have access to a separate water sealed toilet (Central Bank of Sri Lanka, 2008), but data is not available on the type of treatment system that they are connected to. It is a common understanding that almost all the townships are managing septage/nightsoil by emptying the community latrine pits using suction trucks for further treatment or land disposal. Therefore, it is not fully onsite, but a partial onsite system which has to be managed by the local authorities for final disposal.

Partial onsite conventional sanitation systems consist of water sealed latrines, connected to a cesspit or a septic tank allowing the removal of septage or nightsoil to offsite location for further treatment. Physical, chemical and biological characteristics of excreta and water usage required to be considered in applying a treatment technique. The amount of faeces and urine excreted by individuals varies considerably depending upon the water consumption, climate, diet and occupation (Franceys et al., 1992). Average amount of faeces produced per day by an individual is $400 \mathrm{~g}$ and the amount of urine is about $1.0 \mathrm{~L}$ for vegetarian diet in tropical climate (Franceys et al., 1992). Majority of the population in Sri Lanka use water sealed latrines which mix and dilute feces and urine with water producing the 'Black Water'. Fresh faeces contain $10^{5}-10^{9}$ faecal coliform and faecal streptococci per gram (Feachem et al., 1983). Since the faeces contain large amount of microbes, the treatment method should be designed to destroy pathogens.

A given sanitation technology should be able to solve the privacy of excreta disposal, minimize the human and insect contact with excreta, and prevent the damages to the water and environment. Selecting a most appropriate technology requires a thorough analysis of all factors including cost, cultural acceptability, simplicity of design and construction, and operation and maintenance (Franceys et al., 1992). Some sanitation systems in Sri Lanka are operating with many technical, socio-cultural and institutional limitations from the designing phase itself. It is important to assess the already established sanitation systems, and learn their accomplishments and drawbacks before recommending a sanitation technology to a specific area. Some of these factors which lead to success or failure of a system cannot be quantified, but possible to explain in-depth analysis of a case. The objective of the paper was to evaluate the practical issues of POSS that is the most common sanitation system in Sri Lanka.

\section{METHODOLOGY}

A list of onsite and offsite sewage treatment plants in Sri Lanka was prepared and stratified based on the technology. Eight POSSs were selected from each stratum for the detailed assessments, but this paper includes only two case studies that specifically evaluate the sustainability of a POSS. The locations were selected based on the availability of a nightsoil or septage treatment plant which is quite advanced from the direct disposal to lands. 
Data were gathered through a survey including structured interviews with public health inspectors (PHI), operators/caretakers, and users of the sanitation facility. The interview schedule included 28 questions under the main eight categories. Those categories include general details and demographic data in the study area, type of the sanitation system, main components and history, technical details of the system, inflow and outflow characteristics, location specific data on soil and water table, issues on construction, commissioning, and operation, information on institutional coordination, and community participation, and information on environmental and health impacts.

Unstructured interviews with approximately ten households in nearby downstream community, re-users, and sanitary labourers of selected different treatment systems were also carried out. In addition, data gathered during the field visits also were also used in the analysis. The analysis is more qualitative, integrating both quantitative and qualitative data.

\section{RESULTS AND DISCUSSION}

Various treatments and disposal technologies are used in Sri Lanka to treat the transported septage/nightsoil. The most prominent technologies found during the field survey in Sri Lanka are listed in Table 1 under each treatment step.

Whether the technology works or not, most of conventional offsite systems fail due to unexpected variability of incoming sewage to the system. Poor accessibility for gully sucker in some places of urban dwellings, has led to manual removal of septage using sanitary labourers. Though it is dirty, dangerous, demeaning (3D) duty, labourers like to do it as it generates an additional income in addition to their work in the gully sucker. A labourer can earn Rs. 5000 - 6000 per pit by manual emptying of cesspits of an average household. Land disposal of night soil is used to be the prominent method in Sri Lanka, but now declining due to lack of bare lands. Direct disposal to bare land would also cause surface and groundwater pollution. It was interesting to found that some people are willing to and are presently using night soil as a fertilizer which is described in the case study 1 .

The septage could be treated by applying a series of technologies, but the success would depend upon several key factors. Case study 2 elaborates the factors which possibly affect the sustainability of conventional POSS. The user's attention on better management of onsite components are also necessary to prevent continuous blocking of the treatment systems which is clearly shown in the case study 2.

Table 1. The most prominent technologies found in a POSS

\begin{tabular}{ll}
\hline Process & Technology(ies) used in Sri Lanka \\
\hline User Interface \\
$\begin{array}{l}\text { Collection and primary onsite } \\
\text { treatment }\end{array}$ & Water sealed latrine \\
Transportation & Cesspits/septic tanks \\
Collection and storage & Gully sucker trucks/ sewers (rarely) \\
Secondary treatment & Grit chamber/ collection tanks \\
& Anaerobic digesters/ Facultative ponds/Aerated \\
lagoons/Composting in solid waste piles \\
Tertiary treatment & For sludge: Settling tanks/Sludge drying beds \\
& For wastewater: Sand filters/Activated charcoal filters/ \\
Disposal & constructed wetlands \\
& For Sludge: Compost/Land application \\
& For Wastewater: Drain or stream/Land application \\
\hline
\end{tabular}




\section{Case Study 1 - Septage is used as fertilizer in Matara}

\section{Background}

Two to three decades ago, the most common practice for disposal of septage was the land disposal, potentially causing damage to ecosystems, pollution of surface and ground water bodies, and risk for human health. Finding a land for disposal of partially digested sewage became a problem for local governments with rising population and rapid urbanization. The land selected for this purpose should be located in an isolated and remote place from the communities and from the water bodies as well. Therefore, the local governments failed to find a suitable land. Matara municipal council (MC) has solved this problem effectively through a verbal agreement with a coconut land owner, as a short term solution. This practice can be further developed by adopting a proper composting method. Even though this practice can be introduced to other farmers who are willing to use sewage as a fertilizer, it should be sanitized and free of pathogens before applying to the field.

\section{Sanitation system details and prevailing issues}

Matara is a major city located in the coastal belt in southern province of Sri Lanka. Total population of Matara MC area was about 75,000 occupying 12,081 housing units in 2009. Ninety six percent of the population has access to a sanitary latrine and ninety nine percent has access to pipe borne water. Though the access to sanitation facility is very high, the Matara MC encountered some problems of septage management. Natural presence of shallow water table in coastal areas, and high percolation rate of sandy soil in most coastal places hindered the soil treatment of excreta, but it has been managed by constructing septic tanks. The frequent filling of septic tanks led to provide heavy work for the gully suction trucks of the MC. People within the MC boundary have to bear the cost of Rs. 3,136 per one load, whereas it cost about Rs. 26,000 per load for remote places like Deniyaya. The cost is calculated according to the distance to be transported, if it is outside the MC area. Sometimes the truck capacity is not enough to empty the pits. If the pits are located in inaccessible places for the truck, manual removal of septage is done by the skilled sanitary workers. In contrast workers indicated that they have experienced social discrimination because of their job title. This 3D job has affected especially schooling of their children and children's social status. As an example several workers said that their children are going to well recognized colleges, but they cannot tell their father's job to their friends. They say that "sanitary worker in the MC is still not an acceptable job in our society". Continuously exposing to undigested or partially digested sewage also cause health risk to sanitary labourers, but no preventive measures are adopted when loading and unloading the gully truck and/or manual removal. Sometimes the concrete lid of the septic tank must be broken to make the access way, and it may take at least half an hour. Then, kerosene oil is added to the pit to reduce the bad smell. Emptying a cesspit/septic tank is really a dirty task. Therefore, manual emptying of pits are also done very secretly. The Matara MC earns an average profit of Rs. 77,114 per month (Fig. 1) by emptying septic tanks/cesspits. This profit can be used for further treatment of septage, thus reduces the health risk for the re-user and possible environmental hazards. According to the available data, workload for the gully truck follows the same pattern as the rainfall pattern because cesspits and soak pits frequently get filled during the rainy season. 


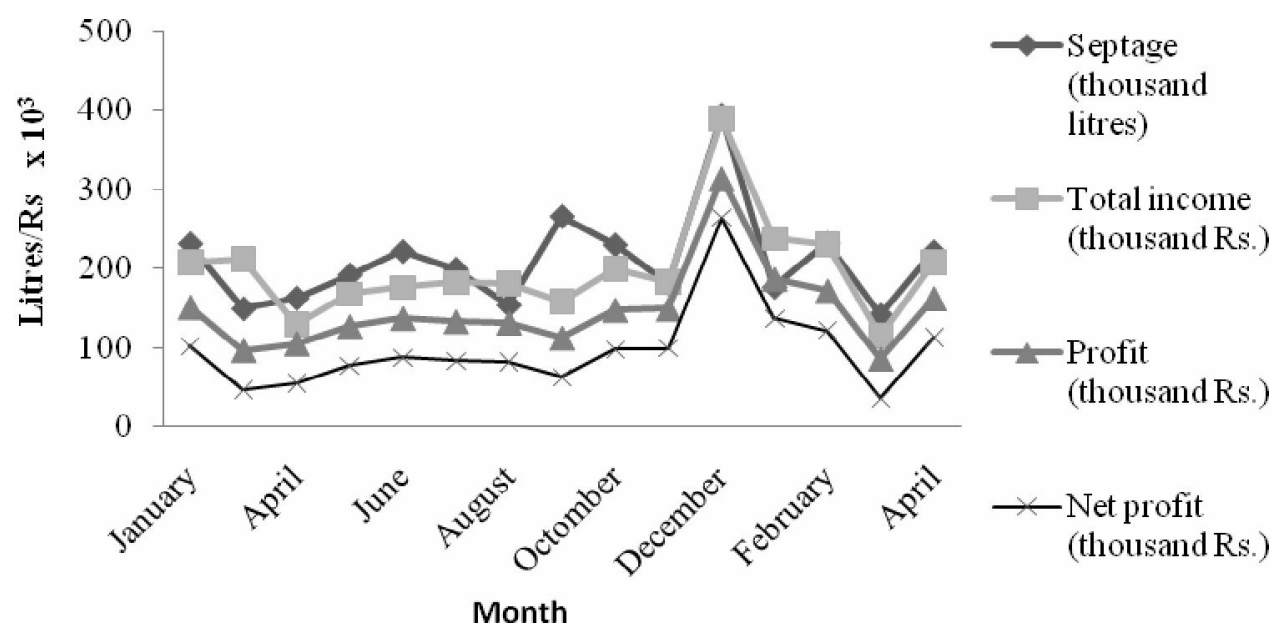

Fig. 1. Workload, income and profits of gully suction trucks for septage transportation. Source: Matara MC

Matara MC uses 70 acres of coconut land to unload the trucks, as a short term solution. Land owner has allowed unloading the trucks into the trenches between coconut trees. This is a very rare case in Sri Lanka, where people have negative attitudes towards using excreta as a fertilizer. Presently the landowner does not use any fertilizer to his cultivation, but he has experienced a $20 \%$ increase of the nut production. Annual savings of fertilizer cost by applying septage is about Rs. 1,000 per acre, thus a total of Rs. 70,000. Since the septage is not fully decomposed, it contains pathogens and would be a host for disease causing organism ultimately making a health risk for the re-users. As an example Ascaris eggs in pit latrines can survive for 1-2 years in cool and wet conditions and if pits are sealed with covering of soil (Feachem et al., 1983). In septic tanks, effluent might be free from Ascaris egg, but the sludge contain considerable amount of eggs according to the literature (Feachem et al., 1983). A study provides evidences on survival of hepatitis A virus in cesspool sludge applied to the farmlands (Raska et al., 1966). Therefore, it is essential to apply a low cost composting mechanism, if the septage is used for agriculture. According to the studies on pathogens removal in excreta, composting has eliminated most of pathogens to undetectable levels. Windrow composting could be applied as a secondary treatment instead of direct application of septage. Many studies revealed that aerobic composting of nightsoil or sludge with woodchips, straw or other carbonaceous material is an efficient method of removing pathogens (Feachem et al., 1983).

\section{Case Study 2 - Partial onsite conventional sanitation system in Negombo}

\section{Background}

Negombo city is located in the western coastal region of Sri Lanka, having a shallow water table throughout the year. The most common sanitation technology used in Negombo city in the user interface is the water sealed latrines with septic tanks or cesspits. According to the statistics in Negombo MC, $98 \%$ of the households in city limits have water sealed latrines, but $95 \%$ out of them are connected to cesspits. Total population within the city limit is 155745 (Negombo municipal council, 2010), and the total black water production is 
approximately $7787 \mathrm{~m}^{3} /$ day. The septic tanks and cesspits get filled frequently creating many nuisances to the people and environment. MC has experienced that 25-30\% of households discharge sewage to storm water drains especially during the rainy days. People earlier used buckets and carts for removal of sewage from filled pits to another new pit. Now the MC is equipped with four gully suction trucks replacing the carts and buckets, also contributing much to the dignity of sanitary labourer. Negombo MC selected a place from the city limits to unload the gully suction truck, but they do not use proper technology to treat the sewage hygienically. The unsafe, unhygienic, and open unloading pit was located close to a stream called 'Diyahondaela', where a rural community is also living nearby. People protested against unloading of sewage because it caused bad smell, wild pig attraction, stream pollution, and health problems in rainy season in the year 2002, the Mayor attended to this matter and invited tenders to construct a Sewage Treatment Plant (STP). The National Engineering Research and Development (NERD) centre was assigned to plan and build a treatment plant close to the present unloading pit. However, the plant was operated only for six months intermittently after commissioning in the year 2005, and the Negombo MC is still unloading the gullies to the old open pit.

\section{Planning and construction process}

The data for planning the STP were taken from the MC gully records maintained by the MC and the input capacity of $125 \mathrm{~m}^{3}$ was determined. The construction process was not commissioned for two years until the site clearance was received from the MC, because of peoples' protests against the discharging of effluent into the stream. After solving the initial issues, construction process had been started and completed within a year. Construction had been smoothly finished by a private contractor according to the plan of the NERD centre. Then the NERD centre proposed a buffer zone and a wall to mitigate the possible nuisances to the neighbour community, and the final effluent was proposed to be discharged into the pit which was used for unloading gullies.

\section{The system details}

The system design consists of grit chamber, two collection tanks, four anaerobic digesters, two aeration tanks, primary and secondary settling tanks, sludge drying beds, sand filter, disinfection tanks, and gas collecting chambers. The designed capacity of a collection chamber was $40 \mathrm{~m}^{3} /$ day. The design sludge capacity was for $1500 \mathrm{mg} / \mathrm{L}$ of total dissolved solids (TSS). The system design had been changed and modified accordingly twice after the initial construction due to the practical problems encountered during the operation. Two separate tanks were also constructed for primary settling and secondary settling.

\section{Technical and socio-economic issues}

The process failed at the primary treatment itself, because the grit chamber was continuously getting blocked due to the unexpected solid parts in gully waste. The scum consisted of polythene, shampoo packets, diapers, sanitary napkins, fish market wastes and even glass bottles. Unexpected load of scum accumulation and sand settling have caused blocking of the system.

The sludge level measured in input sewage was over $30,000 \mathrm{mg} / \mathrm{L}$ of TSS exceeding the designed capacity of $1,500 \mathrm{mg} / \mathrm{L}$. Therefore, the initial settling was not facilitated due to the wrong data used in the design. This is a practical fault of the gully removal process, and the bad management of latrine pits. People have disposed a lot of solid wastes into the latrine 
pits and the solid parts (sand/soil) of broken pits are also come through the gully sucker, resulting high amount of sludge. Sand filling in the grit chamber was also found to be a problem. Filter medium which was coir, get clogged and solidified due to the high sludge level.

Labourers use kerosene to reduce the bad smell that creates bacterial inhibition and a lot of foam formation. The labourers also disclosed the fact that they use one or two kerosene bottles for each pit to reduce the smell during emptying of pits.

Protests of the downstream people towards establishment of the STP caused delay in the commencement. All the respondents from downstream community protested against disposing of toilet waste from the new plant assuming it is hazardous. Even though the downstream people protested against the disposal of treated effluent from the STP, they were unaware of the fact that upstream people directly discharge the overflow to the stream. Most of cesspits could also be observed next to the stream banks but nobody was complaining against it. The stream water is almost black in colour, malodorous, and dirty with solid wastes possibly due to direct inputs of sewage and other wastewater observed in the upstream, but people use the stream for fishing. These evidences prove that the attitudes and knowledge of people towards sewage treatment is very poor.

Poor dignity of sanitary labourer is an issue in conventional POSS because labourers are continuously exposed to sewage, possibly affecting badly on their health. Average monthly salary of a gully labourer is around Rs. 14,000. They spend about 8 hours/day in the gully sucker truck. They are required to complete the list given by the Negombo MC, which normally contains at least 10 locations. Sometimes they receive Rs. $100-150$ per one unit as a courtesy from beneficiaries. According to labourers comments, they are willing to do this job because of the extra income they can earn by manual emptying of pit at places where the truck access is difficult. Labourers give more value to the income, compared to their job status.

A typical household in the MC area usually pays about Rs. 3136 for the removal of one load of septage from their site, which include value added tax and nation building tax but not include any fee for safe disposal. The money invested for the treatment plant was provided by the MC, but still they are unable to commission it successfully.

Septage contains high amount of organic matter, inorganic salts, and fecal microorganisms and needs further treatment before disposal to the natural environment (Herath and Ratnayake, 2008). It is proved that the system works well technically by achieving a high removal rate of TSS, biochemical oxygen demand (BOD) and carbonaceous oxygen demand (COD) along the treatment process (Figures $2 \mathrm{a}, \mathrm{b}$ and c) when it was functioning in 2005. Sampling points along the treatment process are numbered as 0 -Incoming septage, $1-1^{\text {st }}$ digester inlet, 2- $1^{\text {st }}$ digester outlet, $3-2^{\text {nd }}$ digester outlet, 4- $3^{\text {rd }}$ digester outlet, 5- $4^{\text {th }}$ digester outlet, 6- aeration tank 1, 7- aeration tank 2, 8-settling tank outlet, 9- disinfection tank outlet. Increase of inflow above the design level during some period leads to technical failures.

Herath and Ratnayake (2008) showed that septage characteristics vary according to the removal frequency and the source. Therefore, it is difficult to run the system if proper care is not taken by the operators and users of the onsite components. The system design should also be done only after continuous testing of septage characteristics throughout the year. 

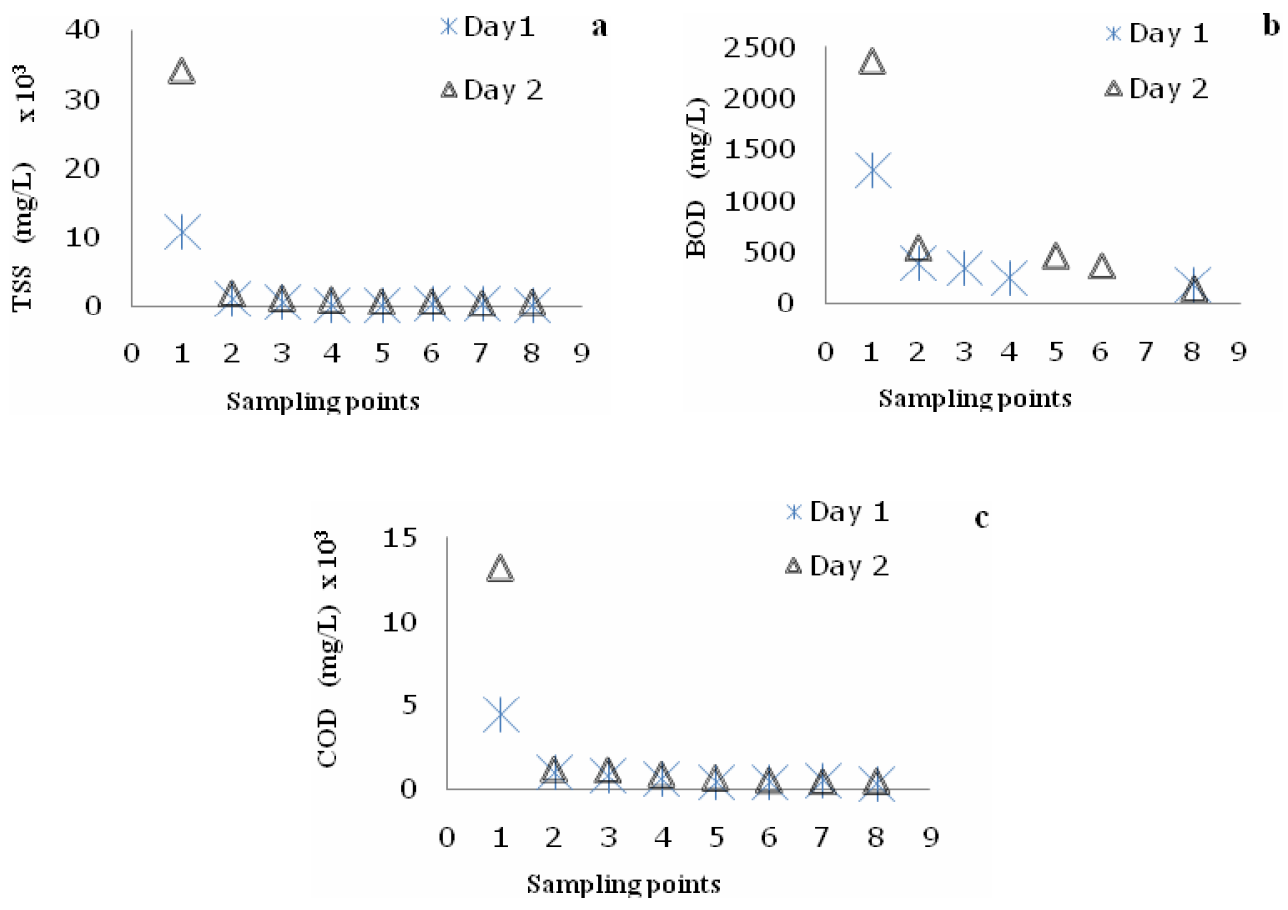

Fig. 2. Removal of TSS (a), BOD (b), COD (c) along the treatment process Source: NERD centre (2009)

\section{Institutional issues}

Several possible reasons for continuous failures of the septage treatment plant were identified through the case study. The major reasons are the lack of technical knowledge of operators on the system, and poor institutional corporation. There was an argument as "the failure is a technical one, which the designer and constructor have to be solved" but it is not only that according to the designer's view and reports. Both institutions highlighted the need of trainings and programs for the responsible officials on sewage management. Money allocation for treatment plant has not been affected by changing political leadership of the MC.

\section{Summary of two case studies}

Septic tanks and cesspits cannot be considered as improved sanitation if the septage is not treated and disposed of safely. As observed in the two case studies; five main factors affecting the sustainability of a POSS were identified as political/institutional support, community participation, and improved knowledge on sanitation, financial management, and technical design. Sustainability of a system ultimately affects social status of sanitary labourer, community health, and environment. The issue network of POSS is shown in Fig. 3. If one of the above factors failed, the system will not be sustainable, and ultimately would affect the health of the sanitary labourer, community as a whole and the environment. 


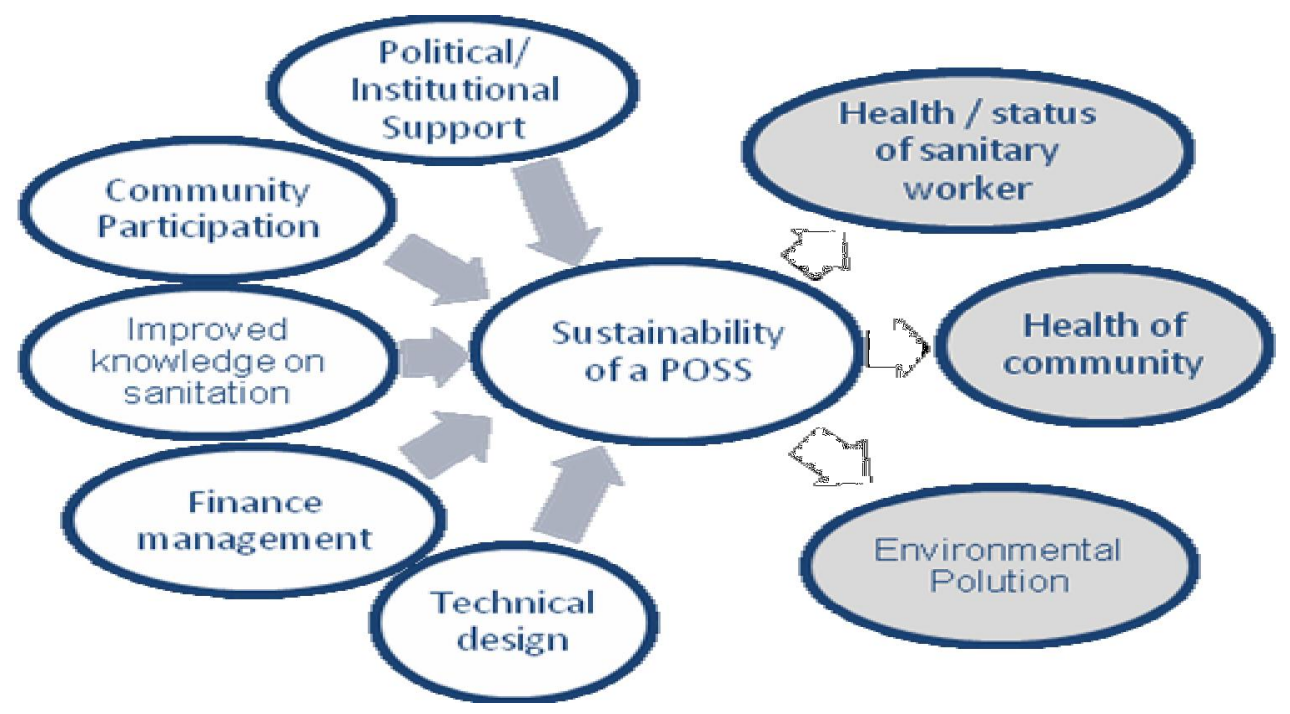

Fig. 3. The schematic diagram for issues of a POSS

The responsibility of regulation, formulation, promotion and monitoring of sanitation services shall be vested with the Central Government, Provincial Councils and Local Authorities. (Ministry of Water Supply and Drainage, 2008). Literature also show that the institutional weakness, lack of expertise, absence of technical and managerial know how, and absence of institutional setup are the major causes of under performances in wastewater management even in some industrialized countries (Hophmayer-Tokich, 2006). Similarly, the two case studies discussed here prove that the same factors have caused failures in a POSS in Sri Lanka. Therefore, profound understanding of above discussed institutional weaknesses and knowledge gap should not be neglected in designing a sustainable sanitation system.

\section{CONCLUSIONS AND RECOMMENDATIONS}

Local authorities attempt to find alternatives for managing septage, instead of direct disposal to a bare land, but the failures have occurred due to many reasons. Those reasons are; poor community participation, poor knowledge on sanitation among officials of the local authorities, and some technical constraints. Some local authorities invest large amount of money on unsafe disposal of septage. The money earned by emptying cesspits and septic tanks can be used to improve the community participation and/or technical performances of the system. All above facts emphasize that the requirement of an institutional setup to monitor and advocate sanitation improvement activities introduced by the local authorities. A national level survey has to be carried out to understand the issues of the sanitation sector. Nevertheless this study indicates the need of capacity building of local authorities for proper sewage management, and creating community awareness to reduce the technical failures of the system. 


\section{ACKNOWLEDGEMENTS}

The authors wish to acknowledge the Crossing Boundaries Project of the PGIA, University of Peradeniya, Sri Lanka, SaciWATERs, Hyderabad, India and the Government of the Netherlands for proving funds and facilities to undertake this research. Furthermore, authors wish to acknowledge the NERD centre, and all the stakeholders who provided data and information required.

\section{REFERENCES}

Central Bank of Sri Lanka. (2008). Annual Report. Special statistical appendix. Available at http://www.cbsl.gov.lk

Feachem, R. G., Bradely, D. J., Garelick, D. and Mara, D. D. (1983). Sanitation and Disease: Health Aspects of Excreta and Wastewater Management, World Bank. pp. 375-393.

Franceys, R., Pickford, J., and Reed, R. (1992). A Guide to Development of Onsite Sanitation. World Health Organization. 1992.

Herath, G. and Ratnayake, U. (2008). Guidelines for the management of septage in Sri Lanka. Report submitted to Oxfam for the sanitation task force. The Department of Civil Engineering, University of Peradeniya, Sri Lanka.

Hophmayer-Tokich, S. (2006). Wastewater management strategy: centralized v. decentralized technologies for small communities. CSTM Study reports. Available at http://www.utwente.nl

Ministry of Water Supply and Drainage (2008). The National Policy for Rural Sanitation (draft) 2006. [on line] [Accessed on 10.06.2010] Available at http://www.cwssp.org

National Engineering Research and Development Centre, (2009). Technical data of the Negombo sewerage treatment plant, working file. NERD centre, Sri Lanka.

Negombo Municipal Council, (2010). Population statistics of Negombo Municipality, Municipal council, Negombo. Sri Lanka.

Raska, K. Helcl, J., Jezek, J., Kubelka, Z.,Litov, M. Novak, K. Radkovsky, J., Sery, V., Zejdl, J. and Zikmund, V. (1966). A milk borne infectious hepatitis epidemic. J. of Hygiene \& Epidemiol. pp. 413-428.

Zurbrügg, C. and Elizabeth, T. (2008). Cyber extension: Evaluation of existing low-cost conventional as well as innovative sanitation system and technologies. [on line] [Accessed on 01.05.2010] Available at http://www.netssaftutorial.com 